\title{
Bax and Calpain Mediate Excitotoxic Oligodendrocyte Death Induced by Activation of Both AMPA and Kainate Receptors
}

\author{
María Victoria Sánchez-Gómez, ${ }^{1,2}$ Elena Alberdi, ${ }^{1,2}$ Esther Pérez-Navarro, ${ }^{1,3}$ Jordi Alberch, ${ }^{1,3}$ and Carlos Matute ${ }^{1,2}$ \\ ${ }^{1}$ Centro de Investigación Biomédica en Red en Enfermedades Neurodegenerativas, ${ }^{2}$ Departamento de Neurociencias, Facultad de Medicina y Odontología, \\ Universidad del País Vasco, 48940 Leioa, Spain, and 3Departamento de Biología Celular, Inmunología y Neurociencias, Facultat de Medicina, Universitat de \\ Barcelona, 08036 Barcelona, Spain
}

\begin{abstract}
Sustained activation of AMPA and kainate receptors in rat oligodendrocytes induces cytosolic calcium overload, mitochondrial depolarization, and an increase of reactive oxygen species, resulting in cell death. Here, we provide evidence that Bax, a proapoptotic member of the Bcl-2 protein family, is involved in excitotoxic apoptotic death of oligodendrocytes and that calpain mediates Bax activation. Cultured $\mathrm{Bax}^{-l-}$ oligodendrocytes, obtained from the optic nerve of Bax knock-out mice, were resistant to AMPA and kainate receptor-mediated insults. In turn, both mitochondrial calcium uptake and mitochondrial alterations after excitotoxic insults were diminished in Bax-null oligodendrocytes. Moreover, pretreatment with furosemide, a blocker of Bax translocation to mitochondria, significantly protected rat and mouse oligodendrocytes from AMPA- and kainate-induced damage; in contrast, bongkrekic acid, a blocker of the mitochondrial permeability transition pore, had no effect. Finally, we analyzed the participation of calpain, which cleaves Bax and is activated by AMPA and kainate, in oligodendrocyte death. Pretreatment with 3-(4-iodophenyl)-2-mercapto-(Z)-2-propenoic acid (PD150606), a broad cellpermeable calpain inhibitor, and two additional calpain inhibitors diminished Bax activation, inhibited its translocation to mitochondria, and attenuated all apoptotic events resulting from excitotoxic insults to rat oligodendrocytes. Together, these results indicate that Bax and calpain are essential intermediaries of the mitochondria-dependent death pathway, triggered by AMPA and kainate receptor activation in oligodendrocytes.
\end{abstract}

\section{Introduction}

Oligodendrocytes express functional glutamate receptors and are highly vulnerable to AMPA and kainate receptor-mediated excitotoxicity, both in vitro (Yoshioka et al., 1996; Matute et al., 1997; McDonald et al., 1998; Sánchez-Gómez and Matute, 1999; Alberdi et al., 2002) and in vivo (Matute, 1998; Follett et al., 2000). Excitotoxic insults to oligodendrocytes are dependent on $\mathrm{Ca}^{2+}$ entry through ionotropic glutamate receptors, which alters $\mathrm{Ca}^{2+}$ homeostasis and induces changes in the mitochondrial membrane, leading to release of proapoptotic molecules such as cytochrome $c$ and apoptosis-inducing factor (AIF). This results in oligodendrocyte death through caspase-dependent and -independent pathways (Alberdi et al., 2002; Sánchez-Gómez et al., 2003; Ness et al., 2004).

The Bcl-2 protein family consists of a network of proapoptotic and antiapoptotic members that interact at both the physical and functional level to regulate mitochondrial integrity and apoptotic death (Tsujimoto, 2003). Antiapoptotic members include Bcl-2 and Bcl-xL, while proapoptotic proteins include the Bax subfamily, such as Bax and Bak, which act as apoptosis executers (Reed,

Received Oct. 25, 2010; revised Dec. 2, 2010; accepted Dec. $27,2010$.

This work was supported by Centro de Investigación Biomédica en Red en Enfermedades Neurodegenerativas (CIBERNED) and by grants from the European Leukodystrophy Association, Ministerio de Educación y Ciencia, Gobierno Vasco, Universidad del País Vasco. We thank M. Domercq for electrophysiological recordings and H. Gómez, 0 . López, and S. Martín for technical assistance.

Correspondence should be addressed to Carlos Matute, Departamento de Neurociencias, Facultad de Medicina y Odontología, Universidad del País Vasco, 48940 Leioa, Spain. E-mail: carlos.matute@ehu.es.

DOI:10.1523/JNEUROSCI.5578-10.2011

Copyright $\odot 2011$ the authors $\quad 0270-6474 / 11 / 312996-11 \$ 15.00 / 0$
1998; Cory and Adams, 2002; Polster and Fiskum, 2004; Ward et al., 2004). The bulk of Bax protein normally resides in the cytosol and translocates to mitochondria upon receiving a variety of apoptotic stimuli (Hsu et al., 1997; Goping et al., 1998). Once inserted into the outer mitochondrial membrane, Bax can exert its proapoptotic action through the formation and/or regulation of channels. This allows the release of intermembrane space proteins into the cytoplasm, including cytochrome $c$, Smac/DIABLO (second mitochondrial activator of caspase/direct IAP binding protein with low $\mathrm{pI}$ ), and AIF, key molecules in mitochondriadependent apoptotic pathways (Tikhomirov and Carpenter, 2005; Lovell et al., 2008; Galluzzi et al., 2009). Those crucial steps require previous activation of Bax protein, but the upstream signaling mechanism responsible for this activation still remains unknown.

Calpains are $\mathrm{Ca}^{2+}$-dependent cysteine proteases that are ubiquitously expressed as two isoforms, $\mu$-and $\mathrm{m}$-calpain, which are activated by micromolar and millimolar concentrations, respectively, of $\mathrm{Ca}^{2+}$. Calpains have been characterized as pivotal mediators of both necrotic and apoptotic cell death following acute hypoxia, traumatic brain injury, chronic degeneration, or excitotoxicity (Gafni and Ellerby, 2002; Liu et al., 2002; Crocker et al., 2003; Nixon, 2003; Mansouri et al., 2007). The potential role of calpains in apoptosis is indicated by a growing list of substrates: $\mathrm{p} 53, \mathrm{I} \kappa \mathrm{B} \alpha, \mathrm{PARP}$, and several cytoskeletal proteins including fodrin and $\alpha$ II-spectrin. Moreover, previous reports suggested calpain can bring about cleavage of Bax protein during apoptosis (Wood et al., 1998) and that the calpain-induced Bax- 
A

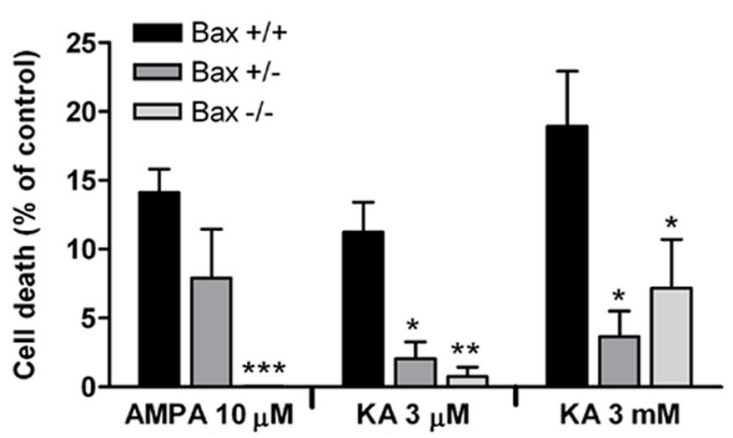

B

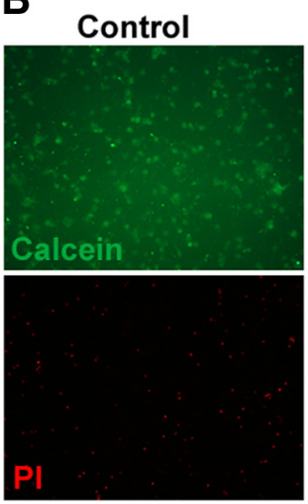

Bax +l+
AMPA $10 \mu \mathrm{M}$

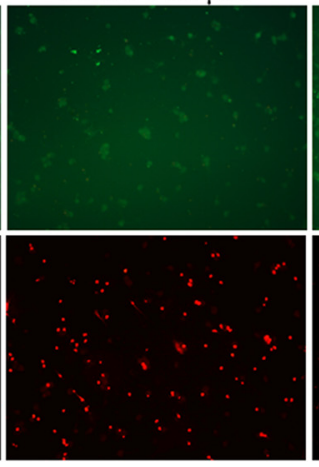

Bax $+1+$
AMPA $10 \mu \mathrm{M}$

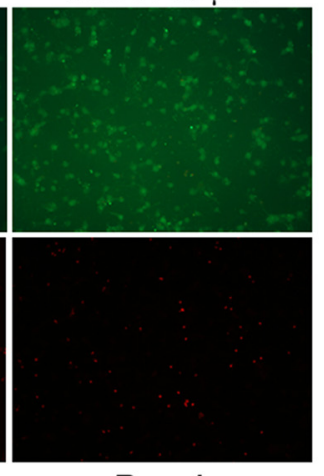

Bax -I-
C

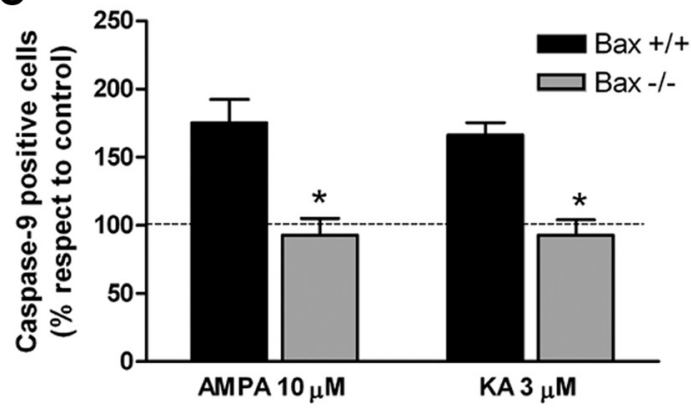

Figure 1. Bax ${ }^{-/-}$oligodendrocytes are resistant to excitotoxic insults. $A$, Oligodendrocyte cultures were obtained from optic nerves of $12-\mathrm{d}-0$ old Bax ${ }^{+/+}$, Bax ${ }^{+/-}$, or Bax ${ }^{-/-}$mice and used for toxicity assays after $1 \mathrm{~d}$ in vitro. Activation of AMPA receptors with $10 \mu \mathrm{m}$ AMPA plus $100 \mu \mathrm{m}$ cyclothiazide for 15 min caused oligodendroglial excitotoxicity in wild-type and Bax $+/-$ cells, while $\mathrm{Bax}^{-1-}$ oligodendrocytes were totally resistant to this insult. In addition, maximal activation of high- or low-affinity kainate (KA) receptors by $3 \mu \mathrm{m}$ or 3 mm kainate plus GYKI53655 caused cell death, which was significantly diminished in oligodendrocytes obtained from Bax ${ }^{+/-}$or Bax-null mice. ${ }^{*} p<0.05,{ }^{* *} p<0.01$, ${ }^{* * *} p<0.001$, compared with Bax ${ }^{+/+}$oligodendrocytes. $\boldsymbol{B}$, Microphotographs representing AMPA toxicity in oligodendrocytes derived from wild-type or Bax ${ }^{-1-}$ mice. Cells were treated as indicated above and stained with calcein-AM (green, living cells) and propidium iodide (red, dead cells) to quantify the effect of agonists. C, Caspase- 9 and caspase-3 activation in Bax ${ }^{+1+}$ and Bax ${ }^{-1-}$ oligodendrocytes after exposure to AMPA or kainate. Activation of AMPA and kainate receptors caused activation of caspase- 9 and caspase- 3 in wild-type oligodendrocytes but not in Bax ${ }^{-1-}$ oligodendrocytes, as determined by immunocytochemistry with antibodies to cleaved caspase- 9 or caspase-3, respectively. ${ }^{*} p<0.05,{ }^{* *} p<0.01,{ }^{* * *} p<0.001$, compared with Bax ${ }^{+/+}$oligodendrocytes.

cleavage product is a more potent inducer of cell death than wild-type Bax (Wood and Newcomb, 2000; Toyota et al., 2003).

The aim of the present work was to determine whether the presence and activation of Bax is critical in AMPA and kainate receptor-induced oligodendrocyte death. In addition, we tested the hypothesis that calpain is a mediator of Bax activation and its translocation to mitochondria, and plays an essential role in triggering the mitochondrial apoptosis pathway in oligodendroglial excitotoxicity.

\section{Materials and Methods}

Oligodendrocyte cultures. Primary cultures of oligodendrocytes derived from the optic nerves of male and female 12-d-old Sprague Dawley rats and mice transgenic for the bax gene were obtained as described previously (Barres et al., 1992), with minor modifications (Alberdi et al., 2002). Cells were seeded into 24 -well plates bearing $14 \mathrm{~mm}$ diameter coverslips coated with poly-D-lysine $(10 \mu \mathrm{g} / \mathrm{ml})$ at a density of $10^{4}$ cells/ well and were maintained at $37^{\circ} \mathrm{C}$ and $5 \% \mathrm{CO}_{2}$ in a chemically defined medium (Barres et al., 1992). Cells were used 2-4 d later for different experiments, at which time, cultures were composed of at least $98 \%$ $\mathrm{O}^{+} /$galactocerebroside $(\mathrm{GalC})^{+}$cells (Alberdi et al., 2002).

Heterozygous Bax (C57BL/6J; Jackson Laboratories) mice were bred to obtain wild-type, $\mathrm{Bax}^{+/-}$, and $\mathrm{Bax}^{-1-}$ genotypes. The genotypes of offspring were confirmed by PCR amplification of DNA extracted from mouse tails, as described previously (Pérez-Navarro et al., 2005).

Toxicity assays. Toxicity assays were performed as described previously (Sánchez-Gómez et al., 2003), with minor modifications. After 2 d in culture, oligodendrocytes were exposed to $100 \mu \mathrm{M}$ cyclothiazide (CTZ) or $100 \mu \mathrm{M}$
GYKI53655 [1-(4-aminophenyl)-4-methyl-7,8-methylenedioxy-5H-2,3benzodiazepine] for $10 \mathrm{~min}$ before incubation with AMPA $(10 \mu \mathrm{M})$ or kainate $(3 \mu \mathrm{M}$ or $3 \mathrm{~mm})$, respectively. Agonists were applied for $15 \mathrm{~min}$, and then the cells were incubated for $24 \mathrm{~h}$ in fresh medium. For treatments with enzyme inhibitors, cells were pretreated with the appropriate dilutions of drugs in conjunction with CTZ or GYKI53655, which remained present during incubation with agonists. Oligodendrocyte viability was assessed $24 \mathrm{~h}$ later by loading cells with $1 \mu \mathrm{M}$ calcein-AM (Invitrogen; C3100) for $30 \mathrm{~min}$ and fluorescence was measured using a Synergy-HT fluorimeter (Bio-Tek Instruments, Inc) as indicated by the supplier ( $485 \mathrm{~nm}$ excitation wavelength and $530 \mathrm{~nm}$ emission wavelength). All experiments were performed in duplicate, and the values provided here are the averages of at least three independent experiments.

$\mathrm{Ca}^{2+}$ imaging in the cytosol. $\left[\mathrm{Ca}^{2+}\right]_{\mathrm{i}}$ was determined as previously described (Grynkiewikcz et al., 1985). Oligodendrocytes were loaded with fura- $2 \mathrm{AM}$ ( $5 \mu \mathrm{M}$; Invitrogen) in culture medium for $30 \mathrm{~min}$ at $37^{\circ} \mathrm{C}$. Cells were washed in HBSS containing 20 mM HEPES, pH 7.4, $10 \mathrm{~mm}$ glucose, and $2 \mathrm{mM} \mathrm{CaCl}_{2}$ (incubation buffer) for $10 \mathrm{~min}$ at room temperature. Experiments were performed in a coverslip chamber continuously perfused with incubation buffer at $4 \mathrm{ml} / \mathrm{min}$. The perfusion chamber was mounted on the stage of a inverted epifluorescence microscope (Zeiss Axiovert 35) equipped with a $150 \mathrm{~W}$ xenon lamp Polychrome IV (T.I.L.L. Photonics) and a Plan Neofluar $40 \times$ oil-immersion objective (Zeiss). Cells were visualized with a high-resolution digital black-and-white white CCD camera (ORCA C4742-80-12 AG; Hamamatsu Photonics). $\left[\mathrm{Ca}^{2+}\right]_{\mathrm{i}}$ was estimated by the $340 / 380$ ratio method, using a $K_{\mathrm{d}}$ value of $224 \mathrm{~nm}$. At the end of the assay, in situ calibration was performed with the successive addition of $10 \mathrm{~mm}$ iono- 
mycin and $2 \mathrm{~m}$ Tris/50 mu EGTA, pH 8.5. Data were analyzed with Excel (Microsoft) and Prism (GraphPad Software) software.

Measurement of mitochondrial $\mathrm{Ca}^{2+}$. Rhod-2 AM (Invitrogen) was used to measure mitochondrial $\mathrm{Ca}^{2+}$ according to the previous procedure with modifications (Hajnóczky et al., 1995). Rhod-2 AM has a net positive charge, which facilitates its sequestration into mitochondria due to membrane potentialdriven uptake. Cells were loaded with $2 \mu \mathrm{M}$ Rhod 2-AM for $30 \mathrm{~min}$. The residual cytosolic fraction of the dye was eliminated when the cells were kept in culture for an additional $4 \mathrm{~h}$ after loading; whereas, the mitochondrial dye fluorescence was maintained. Fluorescence images of Rhod-2 were acquired using $550 \mathrm{~nm}$ excitation and $590 \mathrm{~nm}$ emission. The fluorescence of Rhod-2 was not calibrated in terms of $\left[\mathrm{Ca}^{2+}\right]_{\text {mit }}$ (mitochondrial calcium concentration) since it is not a ratiometric dye.

Measurement of intracellular reactive oxygen species. Accumulation of reactive oxygen species within cells was measured by loading cells with $10 \mu \mathrm{M}$ the oxidation-sensitive fluorescent dye 5- (and-6)-chloromethyl-2', $7^{\prime}$ dichlorodihydrofluorescein diacetate (CMDCFDA) (Invitrogen; C6827) for $20 \mathrm{~min}$ at $37^{\circ} \mathrm{C}$ and $5 \% \mathrm{CO}_{2}$, using $1 \mu \mathrm{M}$ calcein-AM as a control dye. Fluorescence was measured using a Synergy-HT fluorimeter (Bio-Tek Instruments, Inc) and data were expressed as a normalized percentage of CM-DCFDA/calcein fluorescence in controls. Excitation and emission wavelengths for CM-DCFDA were 488 and $515 \mathrm{~nm}$, respectively. All assays were performed in duplicate and the values are the average of at least three independent experiments (mean \pm SEM).

Analysis of mitochondrial membrane potential. Oligodendrocyte cultures were exposed to AMPA or kainate, alone or in presence of different drugs, and the changes in mitochondrial membrane potential were monitored by reduction of 5,5',6,6' -tetrachloro-1,1',3,3' -tetraethylbenzimidazolcarbocyanine iodide (JC-1) (Invitrogen), according to the manufacture's protocol. Briefly, after drug treatment, cells were loaded with $3 \mu \mathrm{M} \mathrm{JC}-1$ in culture medium for 15 $\min$ at $37^{\circ} \mathrm{C}$ and were then washed with HBSS without phenol red two times to eliminate excess dye. In the cytosol, the monomeric form of this dye fluoresces green (emission read at $527 \mathrm{~nm}$ when excited at $485 \mathrm{~nm}$ ); whereas, within the mitochondrial matrix, highly concentrated JC-1 forms aggregates that fluoresce red (emission at $590 \mathrm{~nm}$ when excited at $485 \mathrm{~nm}$ ). Both JC-1 monomers and aggregates were detectable using a Synergy-HT fluorimeter (Bio-Tek Instruments) and the changes in mitochondrial potential were calculated as the red/green ratio for each condition. All experiments $(n \geq 3)$ were performed at least in triplicate and plotted as mean \pm SEM.

Calpain activity assay. The Calpain-Glo Protease Assay (Promega) was used to measure the enzyme activity of calpains on live cells, according to the manufacture's instructions. Oligodendrocytes were seeded onto 98-well plates $\left(2 \times 10^{4}\right.$ cells/well $)$ and incubated at day 2 in vitro with AMPA or kainate, alone or in the presence of the calpain inhibitors 3-(4-iodophenyl)2-mercapto-( $Z$ )-2-propenoic acid (PD150606) (100 $\mu \mathrm{M})$, calpeptin (20 $\mu \mathrm{M})$, or $N-[N-[($ phenylmethoxy)carbonyl $]-\mathrm{L}-\mathrm{valyl}]-$-phenylalaninal (MDL 28170) $(10 \mu \mathrm{M})$. A freshly prepared dilution of the Calpain-Glo Reagent stock solution was added to cells at different times and luminescence was
B

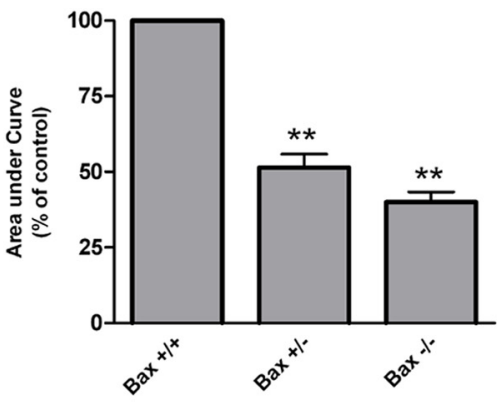

D

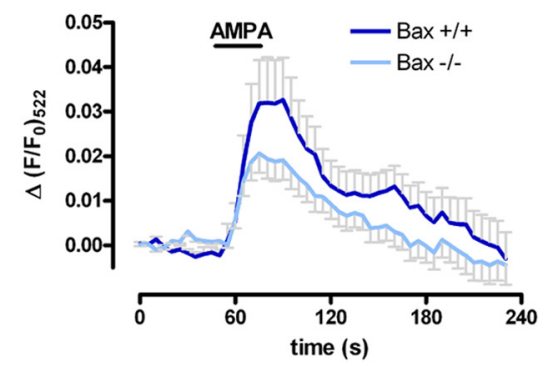

$\mathbf{F}$

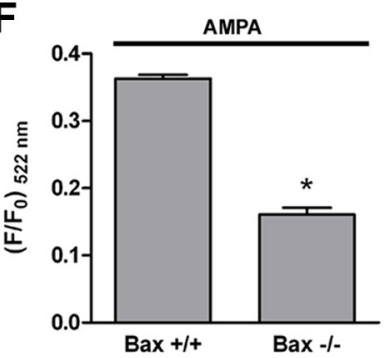

Figure 2. Mitochondrial $\mathrm{Ca}^{2+}$ overload induced by AMPA receptor activation is reduced in $\mathrm{Bax}^{-1-}$ oligodendrocytes. $A, B$, Oligodendrocytes loaded with fura- 2 were exposed to AMPA combined with CTZ in the presence of $F C C P$, and the changes in $\left[\mathrm{Ca}^{2+}\right]_{i}$ were analyzed by microfluorimetry. Selective activation of AMPA receptors, under these conditions, increased the $\left[\mathrm{Ca}^{2+}\right]_{i}$

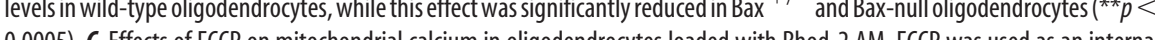
control to release $\mathrm{Ca}^{2+}$ from mitochondria. D. Cells, loaded with Rhod-2 AM, were exposed to AMPA (10 $\left.\mu \mathrm{M}\right)$ plus CTZ (100 $\left.\mu \mathrm{M}\right)$ for 30 s. $\left[\mathrm{Ca}^{2+}\right]_{\text {mit }}$ induced by AMPA was reduced in Bax ${ }^{-/-}$oligodendrocytes compared with Bax ${ }^{+/+}$control cells. Recordings in $\boldsymbol{D}$ illustrate the average \pm SEM responses of 63 cells from at least 5 experiments. $\boldsymbol{E}, \boldsymbol{F}$, Oligodendrocytes, loaded with Rhod-2AM, were exposed to continuous application of AMPA (10 $\mu \mathrm{m}$ plus $100 \mu \mathrm{M}$ CTZ) for $6 \mathrm{~min}$. The histogram represents the average \pm SEM $\left[\mathrm{Ca}^{2+}\right]_{\text {mit }}$ peak maxima for Bax ${ }^{+/+}$and Bax-null oligodendrocytes $\left(n=35\right.$ and 26 , respectively; ${ }^{*} p<0.05$ ).

recorded with a plate reading luminometer (Bio-Tek Instruments Inc). Calpain inhibitors were added for $30 \mathrm{~min}$ before exposure to the agonist, and the assay was conducted in the presence of the inhibitors. All experiments were performed in quadruplicate and the values provided are the calculated average of at least three independent experiments.

Western blotting analysis. Total protein was obtained from oligodendrocytes at specific time points after drug treatment by washing with ice-cold PBS followed by mechanical scraping with $40 \mu \mathrm{l}$ of ice-cold sample buffer per tissue culture dish. The sample was subjected to $8-12 \%$ SDS-PAGE and proteins were electroblotted to nitrocellulose membranes (Hybond ECL, GE Healthcare). After blocking with 5\% nonfat milk for $1 \mathrm{~h}$, the blots were probed with primary antibodies overnight at $4^{\circ} \mathrm{C}$. The blots were incubated with HRP-conjugated anti-IgG for $2 \mathrm{~h}$. After washing, the blots were developed using an enhanced chemiluminescence detection kit, according to the manufacturer's instructions ( $\mathrm{Su}$ per Signal ULTRA, Pierce).

Preparation of cytosolic and mitochondrial proteins. Cytosolic and mitochondrial fractions were prepared as described previously (Kim et al., 
2003). Cells were washed with ice-cold PBS, harvested, and centrifuged at $2000 \mathrm{rpm}$ for $5 \mathrm{~min}$. The supernatant was discarded and the pellet was resuspended in ice-cold lysis buffer $(250 \mathrm{~mm}$ sucrose, $1 \mathrm{~mm}$ sodium EDTA, $0.05 \%$ digitonin, 25 mм Tris [pH 6.8], 1 mм dithiothreitol, 1 $\mu \mathrm{g} / \mathrm{ml}$ leupeptin, $1 \mu \mathrm{g} / \mathrm{ml}$ pepstatin, $1 \mu \mathrm{g} / \mathrm{ml}$ aprotinin, $1 \mathrm{~mm}$ benzamidine, and $0.1 \mathrm{~mm}$ phenylmethylsulfonyl fluoride) and incubated on ice for $30 \mathrm{~min}$. The cells were homogenized by passages through a 27 -gauge needle and then centrifuged at $14,000 \times g$ for $20 \mathrm{~min}$ at $4^{\circ} \mathrm{C}$ to separate the supernatant (mitochondria-free cytosolic extract) and the pellet (mitochondria-containing fraction). Cytosolic or mitochondrial fractions were boiled for $5 \mathrm{~min}$ in sample buffer before they were subjected individually to $8-12 \%$ SDS-PAGE. Protein detection was performed as indicated above. A monoclonal antibody to the mitochondrial protein, cytochrome oxidase subunit IV (COX-IV), was used in Western blotting procedures to assess the success of the fractionation procedure.

Statistical analysis. All data were presented as mean \pm SD. Significant differences among the groups were determined using the unpaired Student's $t$ test. A value of $p<0.05$ was taken as an indication of statistical significance. All the values described in the figures were obtained from at least three independent experiments with similar results.

\section{Results}

AMPA and kainate receptor-induced excitotoxic events in oligodendrocytes are attenuated in the absence of Bax

We previously determined rat oligodendrocytes are vulnerable to excitotoxic signals mediated by AMPA receptors and by high- and low-affinity kainate receptors and that this toxicity is mediated by apoptosis, as suggested by calcium overload, mitochondrial dysfunction, release of cytochrome $c$, and activation of caspase-8, -9, and -3 (Sánchez-Gómez et al., 2003). In addition, the apoptotic process is characterized by morphological features such as loss of plasma membrane asymmetry and exposition of phosphatidylserine (PS), condensation of the nucleus, and fragmentation of DNA. Here, we confirmed excitotoxicity-mediated oligodendroglial cell death is apoptotic by the early presence of PS on the outer leaflet of the lipid bilayer and its labeling with Annexin V-FITC (supplemental Fig. 1, available at www.jneurosci.org as supplemental material). Moreover, we determined that activation of AMPA and kainate receptors triggered late apoptotic nuclear changes such as chromatin condensation and DNA fragmentation, determined by Hoechst staining and the TUNEL assay (supplemental Fig. 2, available at www.jneurosci.org as supplemental material).

We next investigated whether Bax is involved in oligodendrocyte apoptotic death triggered by excitotoxicity. We activated AMPA and kainate receptors in cultures of oligodendrocytes derived from optic nerves of $\mathrm{Bax}^{+/+}, \mathrm{Bax}^{+/-}$, or $\mathrm{Bax}^{-/-}$mice and observed cell death occurs in a genotype-dependent manner. Thus, activation of AMPA receptors with $10 \mu \mathrm{M}$ AMPA plus 100 $\mu \mathrm{M}$ cyclothiazide for 15 min caused oligodendroglial excitotoxicity in wild-type $(14.12 \pm 1.7 \%)$ and $\mathrm{Bax}^{+/-}$cells $(7.93 \pm 3.5 \%)$, while $\mathrm{Bax}^{-/-}$oligodendrocytes were totally resistant $(0.04 \pm$ $0.03 \%$ ) to this insult (Fig. $1 A, B$ ). In addition, maximal activation of high- or low-affinity kainate receptors by $3 \mu \mathrm{M}$ or $3 \mathrm{~mm}$ kainate, respectively, in the presence of the AMPA receptor antagonist GYKI53655 caused cell death in $\mathrm{Bax}^{+/+}$oligodendrocytes $(11.25 \pm 2.2 \%$ and $18.93 \pm 3.9 \%$, respectively), which was significantly diminished when oligodendrocytes were obtained from $\mathrm{Bax}^{+/-}(2.06 \pm 1.2 \%$ and $3.66 \pm 1.9 \%$, respectively) or Bax-null mice $(0.75 \pm 0.6 \%$ and $7.16 \pm 3.5 \%$, respectively; Fig. $1 A$ ).

To further characterize the involvement of Bax in apoptotic signaling cascades, triggered by activation of AMPA and kainate receptors, we analyzed caspase- 9 and caspase- 3 activation in oligodendrocytes derived from $\mathrm{Bax}^{+/+}$or $\mathrm{Bax}^{-/-}$mice after exposure to AMPA or kainate receptor agonists using immu-
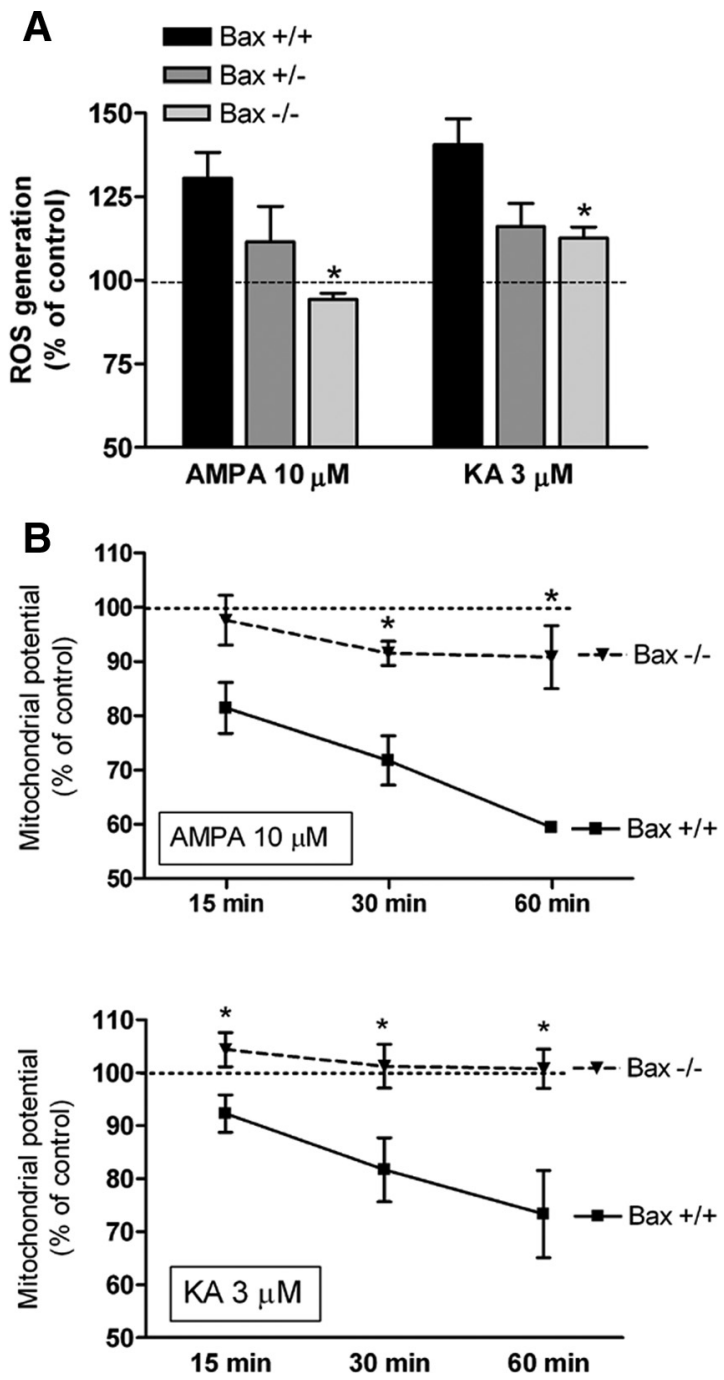

Figure 3. Activation of AMPA and kainate receptors induces ROS generation and loss of mitochondrial potential, which are attenuated in Bax ${ }^{-1-}$ oligodendrocytes. $A, B$, Oligodendrocytes were exposed to the agonists, AMPA or kainate (KA), for $15 \mathrm{~min}$; and ROS generation was determined immediately afterward using the dye DCFDA $(20 \mu \mathrm{M})(\boldsymbol{A})$, and mitochondrial membrane potential was quantified by fluorimetry at different times by loading cells with the dye JC-1 (3 $\mu \mathrm{m})(\boldsymbol{B})$. Levels of ROS and mitochondrial depolarization were attenuated in oligodendrocytes derived from Bax-null mice, compared with cells obtained of wild-type animals $\left({ }^{*} p<0.05\right)$.

nocytochemistry with antibodies that recognize the active form of those caspases (Fig. 1C). Consistent with the levels of cell death shown in Figure $1 A$, the number of cells showing activation of caspase- 9 and caspase- 3 increased following incubation with AMPA or kainate in $\mathrm{Bax}^{+/+}$but not $\mathrm{Bax}^{-/-}$ oligodendrocytes (Fig. 1C).

As a control to exclude the possibility that Bax-null oligodendrocytes had deficient glutamate receptor function, we examined the properties of the responses to AMPA and kainate receptor activation using electrophysiology and $\mathrm{Ca}^{2+}$ imaging. Thus, the amplitude of the electrophysiological currents elicited by activation of each receptor subtype was similar in both $\mathrm{Bax}^{-/-}$and wild-type oligodendrocytes (supplemental Fig. $3 A$, available at www.jneurosci.org as supplemental material). In addition, the increase of cytosolic $\mathrm{Ca}^{2+}$ levels induced by the activation of AMPA and kainate receptors was not affected by the lack of Bax (supplemental Fig. 3B-D, available at www.jneurosci.org as sup- 
plemental material). These results indicate that the functioning of AMPA and kainate receptors in oligodendrocytes is independent of the expression of Bax.

Collectively, these results indicate that selective activation of AMPA and kainate receptors induces Bax-dependent oligodendrocyte apoptotic death. In addition, they show Bax is required for caspase- 9 and caspase- 3 activation after excitotoxic insults mediated by AMPA and kainate receptors, and the lack of Bax protein confers resistance to oligodendrocyte excitotoxicity.

\section{Mitochondrial $\mathrm{Ca}^{2+}$ uptake after exposure to AMPA is diminished in $\mathrm{Bax}^{-1-}$ oligodendrocytes}

Excitotoxic insults evoke a substantial increase in cytosolic $\mathrm{Ca}^{2+}$ levels in oligodendrocytes. The mitochondrion is a major regulator of cytosolic $\mathrm{Ca}^{2+}$ levels $\left[\mathrm{Ca}^{2+}\right]_{\mathrm{i}}$ and massive $\mathrm{Ca}^{2+}$ influx results in mitochondrial $\mathrm{Ca}^{2+}$ overload (Alberdi et al., 2002; Sánchez-Gómez et al., 2003). To examine whether Bax is involved in $\mathrm{Ca}^{2+}$ homeostasis, we used fura- 2 microfluorimetry in oligodendrocytes obtained from $\mathrm{Bax}^{+++}, \mathrm{Bax}^{+/-}$, and $\mathrm{Bax}^{-1-}$ mice after brief exposure $(30 \mathrm{~s})$ to AMPA $(10 \mu \mathrm{M})$ plus CTZ $(100 \mu \mathrm{M})$ (Fig. 2A,B). These experiments were performed in the presence of the mitochondrial proton gradient uncoupler, carbonyl cyanide $p$-trifluoromethoxyphenylhydrazone (FCCP), an agent that dissipates the mitochondrial membrane potential and releases $\mathrm{Ca}^{2+}$ from mitochondria but prevents further $\mathrm{Ca}^{2+}$ uptake (Stout et al., 1998; Carriedo et al., 2000). Mitochondrial depolarization with FCCP, while activating the AMPA receptor, induced a rapid sustained elevation in $\left[\mathrm{Ca}^{2+}\right]_{\mathrm{i}}$ in wild-type oligodendrocytes, with a maximal peak at $910 \pm 144 \mathrm{~nm}(n=30)$, which indicates that a substantial part of calcium is sequestered by mitochondria. This effect is significantly reduced in Bax ${ }^{+/-}$cells $(51.4 \pm 4.4 \% ; n=32)$ and in Bax-null oligodendrocytes $(40.0 \pm 3.4 \%$; $n=34)$, compared with cells obtained from wild-type animals (Fig. 2A,B).

To clarify this event, we next studied mitochondrial $\mathrm{Ca}^{2+}$ uptake in oligodendrocytes with Rhod-2 AM, a cationic indicator that loads selectively into respiring mitochondria. We used FCCP as an internal control. As expected, FCCP induced a rapid and transitory reduction of Rhod-2 fluorescence (Fig. 2C). Under these loading conditions, we assayed the effect of $10 \mu \mathrm{M}$ AMPA plus $100 \mu \mathrm{M} \mathrm{CTZ} \mathrm{on}\left[\mathrm{Ca}^{2+}\right]_{\text {mit }}$ in oligodendrocytes derived from $\mathrm{Bax}^{+/+}$and $\mathrm{Bax}^{-/-}$mice (Fig. 2D). Acute application of AMPA (30 s) rapidly induced a transient increase in $\left[\mathrm{Ca}^{2+}\right]_{\text {mit }}$ levels, compared with the control assay (incubation buffer), in oligodendrocytes expressing Bax protein $(0.033 \pm 0.01$, maximal peak expressed in arbitrary units of fluorescence; $n=36$ ) that was minor in oligodendrocytes obtained from Bax-null mice $(0.021 \pm 0.004 ; n=34$; Fig. $2 D)$. In addition, AMPA (10 $\mu \mathrm{M}$ plus $100 \mu \mathrm{M}$ CTZ) continuously applied for $6 \mathrm{~min}$ in $\mathrm{Bax}^{+/+}$oligo-
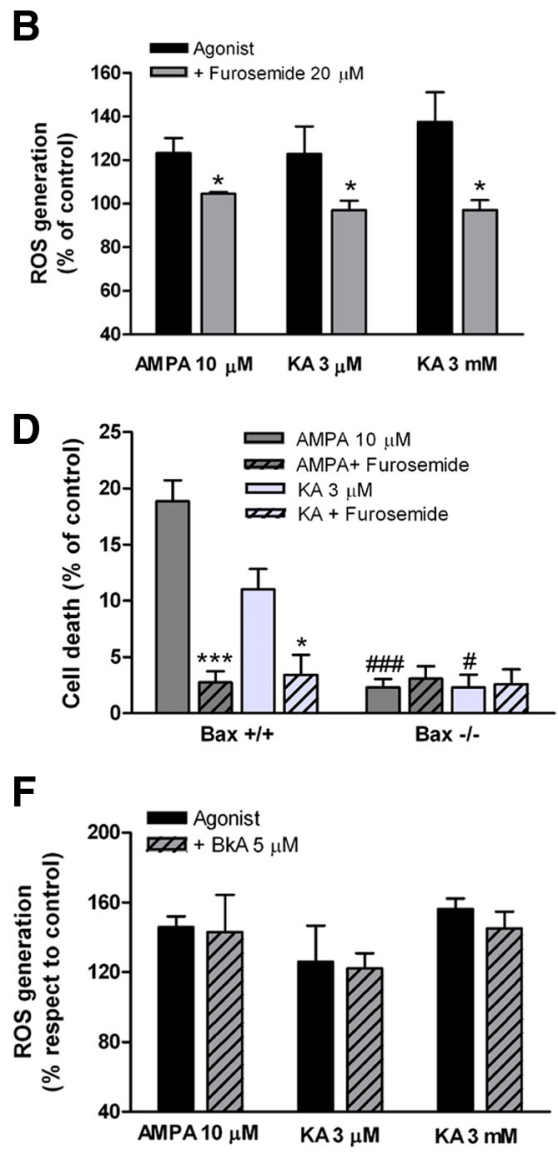

Figure 4. Inhibition of Bax translocation to mitochondria protects oligodendrocytes against AMPA and kainate receptormediated damage. Cultured rat oligodendrocytes were pretreated with furosemide (20 $\mu \mathrm{m})$, a blocker of Bax translocation to

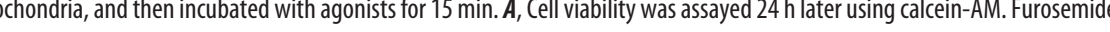
in response to AMPA and kainate (KA) was inhibited by furosemide. $C$, Western blot analysis of Bax expression in the mitochondrial pretreatment for $30 \mathrm{~min}$ ). COX-IV levels were measured as a normalization control. $\boldsymbol{D}$, Toxicity assays were performed in cultured

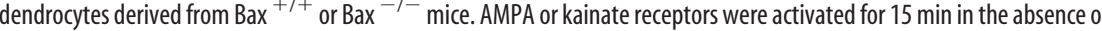
presence of furosemide ( $20 \mu \mathrm{m}$, pretreatment for $30 \mathrm{~min}$ ) and viability was quantified $24 \mathrm{~h}$ later. Cell death was significantly with a blocker of the mitochondrial permeability transition pore (BkA, $5 \mu \mathrm{m}, 30 \mathrm{~min}$ ) before excitotoxic signal induction did not reduce cell death $(\boldsymbol{E})$ or ROS production $(\boldsymbol{F})$ caused by activation of AMPA and kainate receptors. ${ }^{*} p<0.05,{ }^{* *} p<0.01,{ }^{* * *} p<$ 0.001 (cells treated with furosemide vs control cells); ${ }^{\#} p<0.05,{ }^{\# \# \#} p<0.001$ ( $\mathrm{Bax}^{-1-}$ vs Bax ${ }^{+/+}$cells for the same treatment).

dendrocytes induced a rapid and sustained increase in $\left[\mathrm{Ca}^{2+}\right]_{\mathrm{mit}}$ $(0.363 \pm 0.03$, maximal value expressed in arbitrary units of fluorescence; $n=35$ ) that was significantly reduced in oligodendrocytes derived from Bax-deficient mice $(0.161 \pm 0.05 ; n=26 ; p<$ 0.05 ; Fig. $2 E, F)$. These results indicate that activation of AMPA receptors induces mitochondrial $\mathrm{Ca}^{2+}$ overload in mice oligodendrocytes and this effect is attenuated in the absence of Bax protein.

\section{Absence of Bax prevents AMPA and kainate receptor-mediated mitochondrial dysfunction}

Mitochondrial $\mathrm{Ca}^{2+}$ accumulation generates reactive oxygen species (ROS) and causes loss of transmembrane potential (Lenaz et al., 2002), particularly in oligodendrocytes after excitotoxic insults (Sánchez-Gómez et al., 2003). To investigate whether Bax is causally related to these alterations, we determined both ROS production and mitochondrial depolarization in oligodendrocytes derived from mice lacking Bax, after treatment with AMPA or kainate. Using the ROS indicator DCFDA, we observed ROS 
A

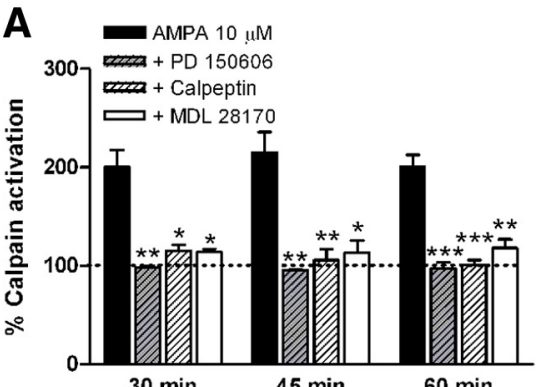

$30 \mathrm{~min}$

C

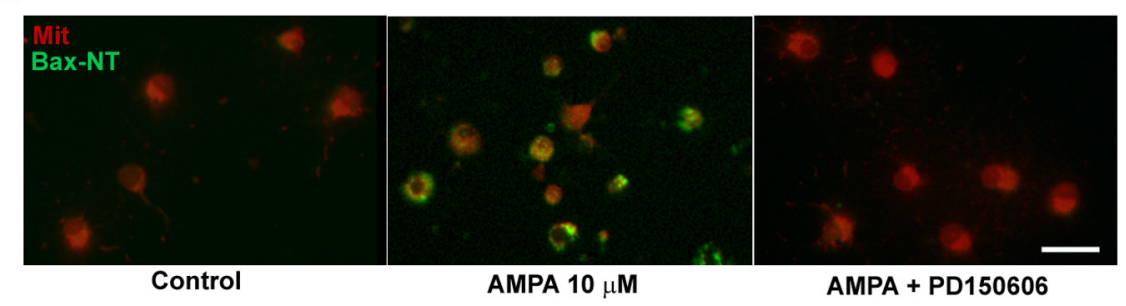

Figure 5. Calpain inhibition prevents Bax activation and translocation after excitotoxicity. $\boldsymbol{A}, \boldsymbol{B}$, Treatment of oligodendrocytes with $10 \mu \mathrm{MAMPA}(\boldsymbol{A})$ or $3 \mu \mathrm{m}$ kainate $(K A)(\boldsymbol{B})$, in the presence of CTZ or GYKI53655, respectively, activates calpain. This effect was prevented by the calpain inhibitors PD150606, calpeptin, or MDL 28170. At different times after treatment, calpain activity was measured in live cells using the Calpain-Glo Protease Assay, and the results are shown as a percentage with respect to the control (untreated cells; 100\%). C, Bax activation and translocation were inhibited by PD150606, a calpain inhibitor. Oligodendrocytes were treated for 15 min with $10 \mu \mathrm{m}$ AMPA plus $100 \mu \mathrm{M}$ CTZ and loaded for 15 min with Mitotracker Orange to identify mitochondria (red). Cells were processed for Bax immunofluorescence using the Bax-NT antibody, which only recognized activated Bax. Exposure to AMPA triggered Bax activation (green) and its translocation into mitochondria (yellow). Those effects were prevented by the calpain inhibitor. Scale bar, $20 \mu \mathrm{m} .{ }^{*} p<0.05,{ }^{* *} p<0.01,{ }^{* * *} p<0.001$.

levels in wild-type oligodendrocytes significantly increased 15 min after activation of AMPA or kainate receptors (up to $130.5 \pm$ 5.5 and $140.0 \pm 5.5 \%$, respectively), an effect that was abolished in Bax-null oligodendrocytes (Fig. 3A).

To monitor the mitochondrial potential, we used the fluorescent probe JC- 1 and quantified its signal at different times poststimulus. As shown in Figure $3 B$, selective activation of both AMPA and kainate receptors induced a reduction in JC-1 fluorescence in $\mathrm{Bax}^{+/+}$oligodendrocytes, which was detected at 15 min poststimulation and was then further enhanced, reaching a peak at $1 \mathrm{~h}$ (up to $59.4 \pm 0.9 \%$ for AMPA and $73.4 \pm 8.2 \%$ for 3 $\mu \mathrm{M}$ kainate, compared with untreated control $\mathrm{Bax}^{+/+}$cells; Fig. $3 B$ ). In contrast, the mitochondrial potential in $\mathrm{Bax}^{-1-}$ oligodendrocytes was not altered by the excitotoxins assayed (90.82 \pm $5.7 \%$ for AMPA and $100.73 \pm 3.7 \%$ for $3 \mu \mathrm{M}$ kainate; Fig. $3 B$ ). Overall, these results indicated that mitochondrial $\mathrm{Ca}^{2+}$ overload subsequent to AMPA and kainate receptor activation causes alterations in mitochondrial function that are dependent on the presence of Bax.

Bax translocation to mitochondria is required for oligodendroglial excitotoxicity, but the mitochondrial permeability transition pore is not involved

The results described above illustrate that Bax mediates the apoptotic death of oligodendrocytes triggered by excitotoxicity. We next analyzed the mechanism by which Bax is involved in apoptosis in this experimental paradigm. Since translocation of Bax into the mitochondria is required for apoptosis (Lin et al., 2005; Perier et al., 2007), we explored the effects of the inhibitor of this event, furosemide (Tafani et al., 2002), to determine whether it is crucial for AMPA and kainate receptor-mediated cell death. Pretreatment with furosemide $(20 \mu \mathrm{M}, 30 \mathrm{~min})$ significantly reduced cell death induced by AMPA $(10 \mu \mathrm{M})$ or kainate ( $3 \mu \mathrm{M}$ and $3 \mathrm{mM})$, in the presence of CTZ or GYKI53655, respectively, on cultured oligodendrocytes obtained from postnatal rat optic nerves (Fig. $4 A$ ). In addition, the presence of furosemide diminished the levels of oxidative stress caused by activation of AMPA and kainate receptors (Fig. $4 B$ ). This suggests Bax translocation to mitochondria is a critical step in apoptosis of oligodendrocytes due to excitotoxicity and its inhibition confers significant protection against AMPA and kainate receptor-mediated damage.

Since furosemide can act on different targets, we examined whether it inhibits the translocation of activated Bax to mitochondria by immunoblotting of mitochondrial fractions obtained from control and AMPA and kainate-treated cells. Indeed, furosemide $(20 \mu \mathrm{M}, 30 \mathrm{~min}) \mathrm{re}-$ versed the increased Bax levels in the mitochondrial fraction as a result of the excitotoxic insults by AMPA and kainate (Fig. 4C). To further assess that furosemide acts on Bax, we assayed its effect on cellular death when applied to oligodendrocytes derived from $\mathrm{Bax}^{-1-}$ mice. As we described above, activation of AMPA or kainate receptors caused cell death in $\mathrm{Bax}^{+/+}$oligodendrocytes $(18.84 \pm 1.8 \%$ and $11.02 \pm 1.8 \%$, respectively); this toxicity was significantly diminished when oligodendrocytes were treated with furosemide $(2.74 \pm 1.0 \%$ and $3.42 \pm$ $1.8 \%$, respectively; Fig. $4 D$ ). However, the residual cell death detected in $\mathrm{Bax}^{-1-}$ oligodendrocytes after stimulation with AMPA or kainate was not affected by furosemide treatment, indicating furosemide is not protective in the absence of Bax.

We also tested whether formation of the mitochondrial permeability transition pore (MPTP) contributed to apoptotic disruption of the mitochondrial membrane potential under our experimental conditions, using the MPTP blocker bongkrekic acid (BkA) (5 $\mu \mathrm{M})$. We found that BkA did not reduce cell death (Fig. $4 E$ ) and did not inhibit ROS induction (Fig. 4F), indicating MPTP does not participate in the excitotoxicity of oligodendrocytes induced by AMPA and kainate receptor activation.

\section{Calpain is involved in Bax activation after AMPA and kainate} receptor activation

Calpain is a $\mathrm{Ca}^{2+}$-activated cysteine protease, which participates in several apoptosis pathways (Liu et al., 2002; Crocker et al., 2003; Mansouri et al., 2007). Since the excitotoxicity of oligodendrocytes is entirely dependent on $\mathrm{Ca}^{2+}$ overload, we initially analyzed whether calpain is activated in oligodendrocytes following treatment with AMPA or kainate agonists. As shown in Figure 5, $A$ and $B$, calpain activity was induced after agonist exposure and was steadily detected for at least $60 \mathrm{~min}$. This effect was prevented when oligodendrocyte cultures were cotreated with the calpain inhibitors PD150606, calpeptin, or MDL 28170. This early induction of calpain activity is consistent with its role as a proximal death signal that may mediate the death process.

Bax is a cytosolic protein that, upon activation by apoptotic stimuli, translocates into the mitochondrial membrane. The mechanisms by which Bax is activated remains largely unknown, but there is evidence that calpain participates in this process 
(Toyota et al., 2003). To test this, oligodendrocytes were treated with AMPA plus CTZ, in the absence or presence of an inhibitor of calpain, PD150606, and loaded with Mitotracker Orange to identify mitochondria. Activation of Bax was determined by immunofluorescence using the Bax-NT antibody, which only recognizes activated-Bax. As shown in Figure $5 C$, cells treated with AMPA showed Bax activation (green) and translocation to mitochondria (yellow, as a result of red and green fluorescence overlap), while both the control and AMPA plus PD150606treated cells did not show activated Bax. Similar results were observed when calpain was inhibited with calpeptin or MDL 28170 (data not shown).

\section{Selective inhibition of calpain} attenuates Bax upregulation, its translocation to mitochondria, and cytochrome $c$ release

To investigate the relationship between calpain activation and Bax regulation during AMPA and kainate-induced apoptosis, we examined further the role of calpain in Bax expression, the translocation of Bax to mitochondria, and the subsequent apoptotic processes. Cultured oligodendrocytes were treated with $10 \mu \mathrm{M}$ AMPA (plus $100 \mu \mathrm{M}$ CTZ) or $3 \mu \mathrm{M}$ kainate (plus $100 \mu \mathrm{M}$ GYKI53655) for $15 \mathrm{~min}$, in the absence or presence of $100 \mu \mathrm{M}$ PD150606, and Bax protein expression and its localization into the cell were assayed by subcellular fractionation and immunoblotting. Figure $6 \mathrm{~A}$ shows a mild increase in total Bax expression, $\sim 1.7$-fold for the sample treated with AMPA and 1.9-fold for cells treated with kainate, compared with controls.

To analyze whether Bax translocation into the mitochondria occurred through calpain-mediated mechanisms, both mitochondrial and cytosolic fractions were prepared from untreated and AMPA and kainate-treated cells in the presence or absence of the calpain inhibitor PD150606. The relatively small amount of Bax found in the mitochondrial fraction of control cells increased up to $235.8 \pm 28.9 \%$ in the mitochondria of oligodendrocytes treated with $10 \mu \mathrm{M}$ AMPA and up to $182.6 \pm$ $20.6 \%$ for $3 \mu \mathrm{M}$ kainate, indicating translocation of Bax into the mitochondria was induced by AMPA and kainate receptors (Fig. $6 B$ ). Furthermore, and in accordance with the observations in mitochondria, there was a significant reduction of Bax protein in the cytosol fraction $(64.04 \pm 5.4 \%$ for AMPA and $75.38 \pm 10.1 \%$ for kainate, compared with control cells). This occurred concomitantly with an increase of cytochrome $c$ levels in the cytosol $(190.4 \pm 14.5 \%$ after AMPA and $237.1 \pm 12.2 \%$ after kainate treatment) (Fig. 6C). In all instances, pretreatment with the calpain inhibitor PD150606 (100 $\mu \mathrm{M}, 30 \mathrm{~min})$ before the excitotoxic stimuli prevented Bax translocation into mitochondria as well as treated with agonist alone.
B Mitochondrial fraction
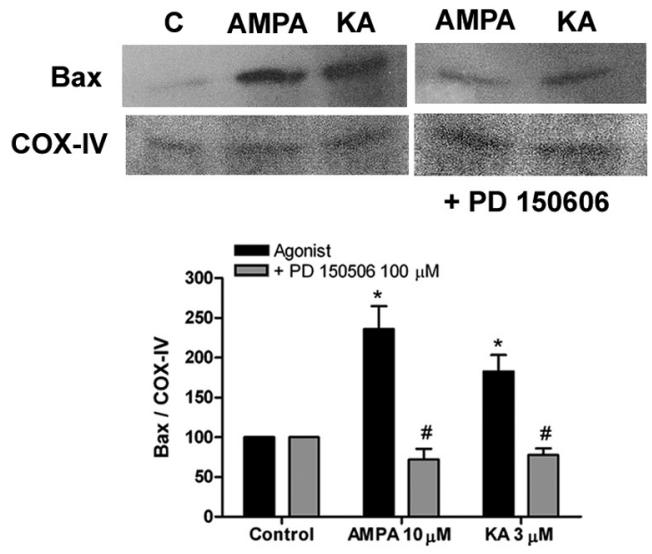

C

Cytosolic fraction
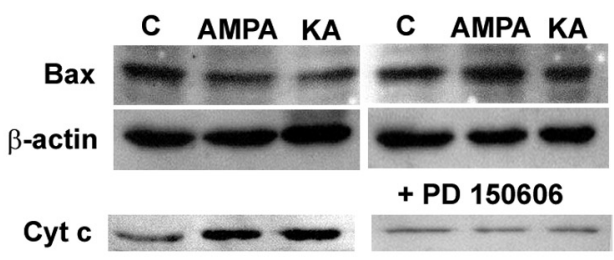

+ PD 150606
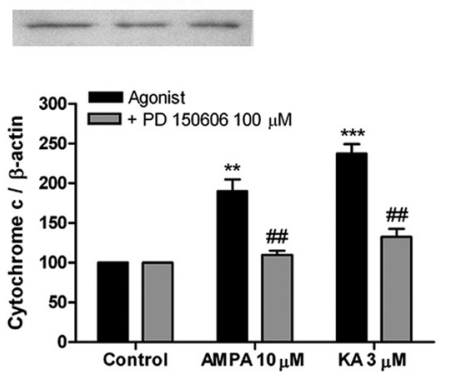

Figure 6. Activation of AMPA and kainate receptors induces Bax upregulation, as well as Bax translocation to mitochondria and cytochrome c release, which are calpain dependent. Cultured oligodendrocytes were stimulated with AMPA (10 $\mu$ M, plus $100 \mu \mathrm{M}$ CTZ) or kainate (KA) (3 $\mu \mathrm{m}$, plus $100 \mu \mathrm{m}$ GYKI53655) for $15 \mathrm{~min}$, with or without the calpain inhibitor PD150606 (100 $\mu \mathrm{m}$ ). After $30 \mathrm{~min}$, both total Representative blots for Bax expression in total cell lysates obtained from oligodendrocytes treated with agonists. Quantification of the bands showed Bax upregulation as a consequence of AMPA and kainate receptor activation. $\beta$-Actin levels were measured as a normalreceptor activation, which was abolished with the calpain inhibitor PD150606. The histogram illustrates the quantitative analysis and that agonists caused an elevation of up to 2.5-fold of the mitochondrial Bax level, compared with the control, and the presence of cin cytosolic fractions of oligodendrocytes treated with AMPA or kainate, alone or in combination with PD150606. Treatment with agonists a sicant decrease in the cytosolic Bax expression level that was paralleled by an increase in the cytochrome clevel. Asshown by

the subsequent release of cytochrome $c$ into the cytosol (Fig. $6 \mathrm{~B}, \mathrm{C})$. All the above results suggest AMPA and kainate receptormediated calpain activation participates in both translocation of Bax from the cytosol into mitochondria and release of cytochrome $c$ into the cytosol, key steps in the mitochondriadependent apoptotic pathways triggered by excitotoxicity in oligodendrocytes.

\section{Calpain inhibition protects oligodendrocytes from events} induced by excitotoxicity

The results above provide evidence that Bax processing is required for excitotoxic death and that calpain is involved in Bax activation. We next analyzed whether calpain inhibition prevents toxicity and the mitochondrial alterations that occur during oli- 
A

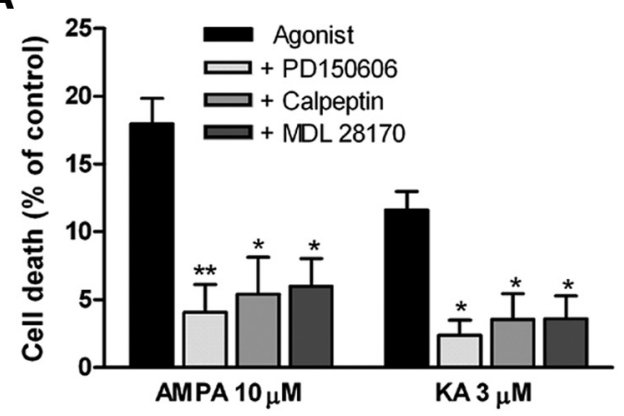

B
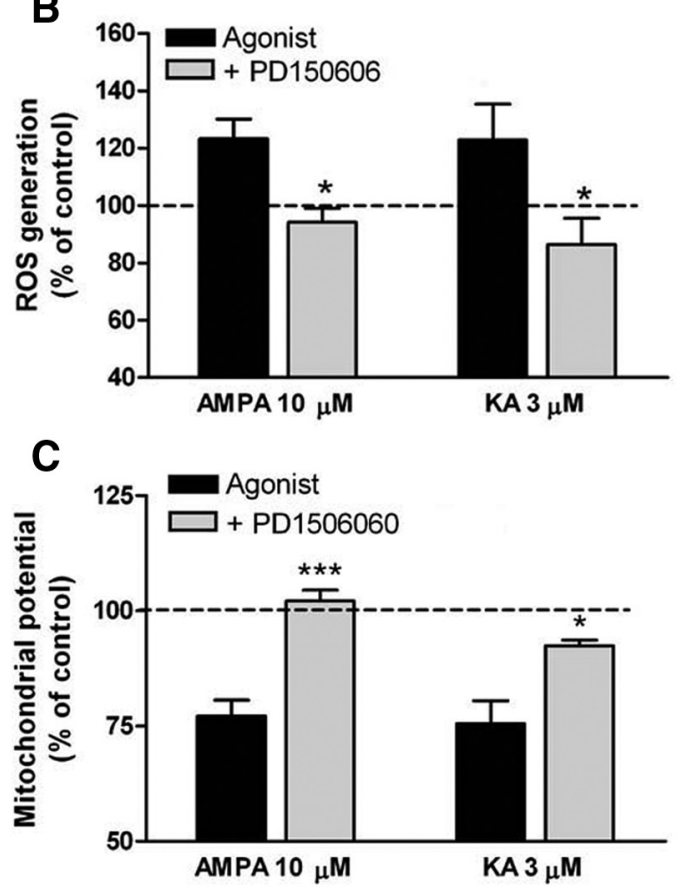

Figure 7. Calpain inhibition reduces oligodendroglial death and mitochondrial alterations in response to excitotoxicity. Cells were treated with AMPA and kainate (KA) receptor agonists for $15 \mathrm{~min}$, in the absence or presence of calpain inhibitors PD150606 (100 $\mu \mathrm{M})$, calpeptin $(20 \mu \mathrm{M})$, or MDL $28170(10 \mu \mathrm{M})$. A, Cell viability was determined by a calcein-AM assay after $24 \mathrm{~h}$. All calpain inhibitors used significantly reduced oligodendrocyte death caused by AMPA or kainate exposure. $B, C$, ROS production and mitochondrial potential were monitored by measuring DCFDA $(20 \mu \mathrm{M})$ and JC-1 $(3 \mu \mathrm{m})$ fluorescence, respectively. The presence of PD150606 inhibited AMPA and kainate receptor-mediated ROS generation and mitochondrial depolarization. ${ }^{*} p<$ $0.05,{ }^{* *} p<0.01,{ }^{* * *} p<0.001$, compared with cells treated with agonist alone.

godendroglial excitotoxicity. We treated cultured oligodendrocytes with AMPA plus CTZ (10 and $100 \mu \mathrm{M}$, respectively) or kainate plus GYKI53655 (3 and $100 \mu \mathrm{M}$, respectively), in the absence or presence of calpain inhibitors, and monitored cell death, ROS, and mitochondrial potential. Calpain inhibition by PD150606, calpeptin, or MDL 28170 attenuated oligodendrocyte death induced by AMPA and kainate receptors (Fig. $7 A$ ). In turn, ROS generation and mitochondrial depolarization resulting from those excitotoxic insults were attenuated in the presence of PD150606 (Fig. 7B,C), calpeptin, or MDL 28170 (data not shown).

In a previous study (Sánchez-Gómez et al., 2003), we demonstrated that caspase- 3 activation is involved in AMPA and kainate receptor-mediated apoptosis of rat cultured oligodendrocytes. To determine whether caspase- 3 activation was also affected by calpain inhibition, we performed immunoblotting to evaluate the levels of procaspase- 3 and cleaved caspase- 3 in oligodendro- cytes treated with or without calpain inhibitor during AMPA and kainate receptor stimulation. Western blots with antibodies recognizing the $32 \mathrm{kDa}$ proenzyme and the $17 \mathrm{kDa}$ fragment were done with protein extracts harvested after $4 \mathrm{~h}$ of treatment. The results are shown in Figure 8. A significant decrease in procaspase-3 levels was detected in agonist-treated oligodendrocytes $(75.8 \pm 4.0 \%$ for $10 \mu \mathrm{M}$ AMPA and $63.9 \pm 3.8$ for $3 \mu \mathrm{M}$ kainate, compared with the control; Fig. $8 A, B$ ), which was paralleled by a significant elevation in the active caspase- 3 level $(154.8 \pm 26.6 \%$ for $10 \mu \mathrm{M}$ AMPA and $197.34 \pm 35.4 \%$ for $3 \mu \mathrm{M}$ kainate, with respect to the control; Fig. $8 A, C$ ). Both the decrease in the procaspase-3 protein level and increase in cleaved caspase- 3 were completely prevented in the presence of the calpain inhibitor, suggesting the involvement of calpain in caspase-3 activation after excitotoxicity.

In sum, calpain inhibition reduces oligodendrocyte death, diminishes reactive oxygen species, prevents mitochondrial depolarization, and inhibits caspase- 3 activation. These results indicate that AMPA and kainate receptor-mediated calpain activation is involved in apoptotic oligodendrocyte death by altering mitochondria function and inducing caspase-3 activation.

\section{Discussion}

The results reported here show that apoptosis induced by excitotoxicity in optic nerve oligodendrocytes is mediated by Bax. In addition, we found calpain is activated in response to excitotoxic insults initiated by AMPA and kainate receptors, and that its activation is required to turn on Bax and induce apoptotic cell death through mitochondria-dependent death pathways. In a previous study, we found activation of AMPA and kainate receptors in oligodendrocytes results in $\mathrm{Ca}^{2+}$ influx and subsequent mitochondrial dysfunction, consisting of mitochondrial $\mathrm{Ca}^{2+}$ overload, oxidative stress, and membrane depolarization, which ultimately results in caspase activation and apoptotic cell death (Sánchez-Gómez et al., 2003). In the current study we have observed those lethal events are prevented in the absence of Bax or by pharmacological inhibition of calpain. These results are consistent with the known protective effect of Bax deficiency in various experimental models, both in vivo and in vitro. Knock-out of Bax confers neuroprotection in mouse models of Parkinson's disease (Vila et al., 2001; Perier et al., 2007), ischemia (Gibson et al., 2001), excitotoxicity (Pérez-Navarro et al., 2005), and trauma (Tehranian et al., 2008); reduces oligodendroglial injury after spinal cord hemisection (Dong et al., 2003); and attenuates the clinical signs of experimental autoimmune encephalomyelitis by diminishing apoptotic cell death of oligodendrocytes (Lev et al., 2004).

Absence of Bax also grants resistance against toxic stimuli in different in vitro models in a variety of cell types derived from the nervous system, such as neurons (Cregan et al., 1999; Steckley et al., 2007), astrocytes (Yung et al., 2004), oligodendrocytes (Ness et al., 2004; Liu et al., 2006; Pang et al., 2007; Hossain et al., 2009), or neuroblastoma cells (Gómez-Lázaro et al., 2007), and from other tissues, such as lung (Oh et al., 2004; Wu et al., 2007), liver (Park et al., 2007), or epithelium (Owens et al., 2009).

In line with those findings, we observed that oligodendrocytes are resistant to excitotoxic insults in the absence of Bax, which interrupts the cascade of events leading to mitochondrial dysfunction. Thus, oligodendrocytes lacking Bax displayed less intense mitochondrial $\mathrm{Ca}^{2+}$ overload than did their wild-type counterparts and, hence, attenuated depolarization of the mitochondrial membrane, which is an early event in apoptosis (for review, see Atlante et al., 2001; Skulachev, 2006), as well as re- 
duced oxidative stress. These observations indicate that Bax is required to distort mitochondrial function triggered by excitotoxic insults to oligodendrocytes, as proposed recently for neurons (Gavaldà et al., 2008). Bax-deficient striatal neurons respond to excitotoxicity by upregulating other proapoptotic proteins, but are resistant to excitotoxicity themselves. This reveals Bax as a mediator of the mitochondrial phase of apoptosis and an essential protein for execution of cell death in response to excitotoxicity (Gavaldà et al., 2008).

Translocation of Bax protein from the cytosol into the mitochondrial membrane is a necessary event to trigger mitochondrial dysfunction and induce apoptosis (Hsu et al., 1997; Itoh et al., 2003; Lin et al., 2005; Perier et al., 2007; Gavathiotis et al., 2008; Galluzzi et al., 2009). Here, we provided evidence indicating that Bax translocation into mitochondria is required for excitotoxic apoptosis in oligodendrocytes. Furosemide, a Bax translocation blocker (Tafani et al., 2002), reduced both ROS generation and cell death upon excitotoxic exposure. Similarly, inhibiting Bax translocation with furosemide significantly protects neurons against ischemiainduced damage (Lin et al., 2005) and attenuates the extent of malonate-induced apoptosis in neuroblastoma cells (Gómez-Lázaro et al., 2007). In addition, preventing Bax translocation with IGF-I also disrupts the glutamate-mediated apoptotic pathway in oligodendrocyte progenitors (Ness et al., 2004).

Bax is constitutively present in the cytosol of healthy oligodendrocytes; although, its expression levels vary during development and maturation (Madison and Pfeiffer, 1996; Khorchid et al., 2002; Osterhout et al., 2002). This is in contrast to the limited expression of anti-apoptotic proteins $\mathrm{Bcl}-2$ and $\mathrm{Bcl}-\mathrm{xl}$, implying cells of oligodendrocyte lineage are always ready to die in response to various apoptotic signals via the intrinsic pathway (Itoh et al., 2003; Danial and Korsmeyer, 2004).

In the current study, we observed by immunoblotting that Bax is present in a constitutive manner in oligodendrocytes derived from the rat optic nerve, and Bax expression significantly increased upon excitotoxic insults mediated by AMPA and kainate receptors. Similarly, increased expression of Bax occurs in response to lethal signals to oligodendrocytes (Jamin et al., 2001; Genc et al., 2003; Liu et al., 2006) and after CNS injury (for review, see Gavaldà et al., 2008). In other systems, Bax expression is induced, normally by activation of $\mathrm{p} 53$, upon damage to the genome or interference with the normal progression of the cell cycle (for review, see $\mathrm{Wu}$ and Deng, 2002). However, whether Bax is constitutively expressed or induced, its primary action results from its translocation from the cytosol to the mitochondria (Tafani et al., 2002), as indicated by our results. However, the mechanisms by which Bax becomes activated are not currently known; although, several possibilities have been proposed. Some models suggest $\mathrm{BH} 3$-only proteins, such as Bim and tBid, can bind directly to Bax and Bak, or indirectly through antiapoptotic Bcl-2 proteins, and promote Bax activation (Kuwana et al., 2005; Chipuk et al., 2006; Gavathiotis et al., 2008). On the other hand, Bax function can be regulated by cleavage of its $\mathrm{N}$-terminal domain, which is necessary for maintaining Bax in its cytosolic conformation. Elimination of the domain renders the protein constitutively localized to the mitochondria, increases its intrinsic cytotoxic properties, and enhances its deleterious potential (Wood and Newcomb 2000). An alternative idea proposes the $\mathrm{N}$ terminus of Bax can be cleaved by calpain to produce its potent proapoptotic isoform, which has greater affinity for mitochondrial membrane insertion (Wood et al., 1998; Toyota et al., 2003; Oh et al., 2004). These findings, along with the involvement of calpains in excitotoxic-mediated cell death (Choi, 1988; Liu et al., 2002; Rami, 2003; Mansouri et al., 2007) and myelin destruction by glutamate (Fu et al., 2009), led us to examine whether these proteases are related to Bax activation in oligodendrocytes following insults with AMPA and kainate. We observed that calpain was activated in oligodendrocytes exposed to glutamate receptor agonists and that its activity was abolished by calpain inhibitors. In addition, using the Bax-NT antibody, which recognizes an $\mathrm{N}$-terminal epitope exposed after Bax activation (Nechushtan et al., 1999), we observed an association between calpain activation and the functional status of Bax. Calpain inhibition during AMPA and kainate exposure resulted in an absence of Bax activation. Finally, calpain inhibition preserved mitochondrial function and integrity and prevented the translocation of Bax after the insult, subsequent cytochrome $c$ release, caspase- 3 activation, and oligodendroglial cell death. These results strongly suggest calpain activity is required for activation of the mitochondrial apoptosissignaling pathway in oligodendrocytes, in a Bax-dependent manner, similar to findings by others in different models (Liu et al., 2002; Oh et al., 2004; Mansouri et al., 2007).

Despite the remarkable increase in Bax level detected in the mitochondrial fraction after AMPA and kainate exposure, the reduction of cytosolic Bax was relatively small, although statistically significant and sufficient to trigger the release of cytochrome 
$c$ into the cytosol. This may have been due to the high abundance of Bax in the cytosol in control conditions, as discussed above, which could mask the reduction that occurs during the translocation process. It was previously suggested that translocation of $\sim 20 \%$ of cellular Bax to the mitochondria may be sufficient to induce apoptosis (Annis et al., 2001).

Once inserted into mitochondria, Bax could trigger oligodendroglial death by permeabilization of the outer mitochondrial membrane, thereby releasing cytochrome $c$ into the cytosol. This would cause activation of caspase 9 through formation of the procaspase-9/Apaf-1 complex in the presence of adenosine triphosphate, resulting in activation of executor caspases (Hengartner, 2000). Although the mechanism by which Bax induces cytochrome $c$ release is still a matter of intense debate, our data indicate, in the context of oligodendroglial excitotoxicity, that it seems to be independent of the mitochondrial permeability transition pore. Pretreatment of oligodendrocytes with bongkrekic acid, a blocker of the mitochondrial pore, do not attenuate ROS formation or protect against AMPA or kainate-induced toxicity. It is possible that insertion of Bax into the mitochondrial membrane causes its oligomerization, thus favoring the formation of ion-channels in liposomes or planar lipid membranes; such ion channels can participate in the release of cytochrome $c$ from mitochondria to the cytosol (for review, see Galluzzi et al., 2009).

In summary, our data indicate that Bax and calpain are mediators of excitotoxicity-mediated apoptosis in oligodendrocytes, emphasize the central role of calpain in the regulation of Bax upon these death stimuli, and demonstrate that calpain inhibition protects oligodendrocytes from excitotoxic insults. On the basis of our results, we propose that activation of AMPA and kainate receptors triggers sustained calpain activation, which induces the insertion of Bax into the outer membrane of mitochondria. This event leads to mitochondrial dysfunction, release of cytochrome $c$ into the cytosol, and subsequent caspase activation leading to apoptotic cell death. Drugs that modulate these death pathways can prevent excitotoxic damage to oligodendrocytes and reduce the injuries that are the basis of demyelinating disorders.

\section{References}

Alberdi E, Sánchez-Gómez MV, Marino A, Matute C (2002) $\mathrm{Ca}^{2+}$ influx through AMPA or kainate receptors alone is sufficient to initiate excitotoxicity in cultured oligodendrocytes. Neurobiol Dis 9:234-243.

Annis MG, Zamzami N, Zhu W, Penn LZ, Kroemer G, Leber B, Andrews DW (2001) Endoplasmic reticulum localized Bcl-2 prevents apoptosis when redistribution of cytochrome $c$ is a late event. Oncogene 20:1939-1952.

Atlante A, Calissano P, Bobba A, Giannattasio S, Marra E, Passarella S (2001) Glutamate neurotoxicity, oxidative stress and mitochondria. FEBS Lett 497:1-5.

Barres BA, Hart IK, Coles HS, Burne JF, Voyvodic JT, Richardson WD, Raff MC (1992) Cell death and control of cell survival in the oligodendrocyte lineage. Cell 70:31-46.

Carriedo SG, Sensi SL, Yin HZ, Weiss JH (2000) AMPA exposures induce mitochondrial $\mathrm{Ca}(2+)$ overload and ROS generation in spinal motor neurons in vitro. J Neurosci 20:240-250.

Chipuk JE, Bouchier-Hayes L, Green DR (2006) Mitochondrial outer membrane permeabilization during apoptosis: the innocent bystander scenario. Cell Death Differ 13:1396-1402.

Choi DW (1988) Glutamate neurotoxicity and disease of the nervous system. Neuron 1:623-634.

Cory S, Adams JM (2002) The Bcl2 family: regulators of the cellular life-ordeath switch. Nat Rev Cancer 2:647-656.

Cregan SP, MacLaurin JG, Craig CG, Robertson GS, Nicholson DW, Park DS, Slack RS (1999) Bax-dependent caspase-3 activation is a key determinant in p53-induced apoptosis in neurons. J Neurosci 19:7860-7869.

Crocker SJ, Smith PD, Jackson-Lewis V, Lamba WR, Hayley SP, Grimm E, Callaghan SM, Slack RS, Melloni E, Przedborski S, Robertson GS, Anisman H, Merali Z, Park DS (2003) Inhibition of calpains prevents neu- ronal and behavioral deficits in an MPTP mouse model of Parkinson's disease. J Neurosci 23:4081-4091.

Danial NN, Korsmeyer SJ (2004) Cell death: critical control points. Cell 116:205-219.

Dong H, Fazzaro A, Xiang C, Korsmeyer SJ, Jacquin MF, McDonald JW (2003) Enhanced oligodendrocyte survival after spinal cord injury in bax-deficient mice and mice with delayed Wallerian degeneration. J Neurosci 23:8682-8691.

Follett PL, Rosenberg PA, Volpe JJ, Jensen FE (2000) NBQX attenuates excitotoxic injury in developing white matter. J Neurosci 20:9235-9241.

Fu Y, Sun W, Shi Y, Shi R, Cheng JX (2009) Glutamate excitotoxicity inflicts paranodal myelin splitting and retraction. PLoS One 4:e6705.

Gafni J, Ellerby LM (2002) Calpain activation in Huntington's disease. J Neurosci 22:4842-4849.

Galluzzi L, Blomgren K, Kroemer G (2009) Mitochondrial membrane permeabilization in neuronal injury. Nat Rev Neurosci 10:481-494.

Gavaldà N, Pérez-Navarro E, García-Martínez JM, Marco S, Benito A, Alberch J (2008) Bax deficiency promotes an up-regulation of Bim ${ }_{\mathrm{EL}}$ and Bak during striatal and cortical postnatal development, and after excitotoxic injury. Mol Cell Neurosci 37:663-672.

Gavathiotis E, Suzuki M, Davis ML, Pitter K, Bird GH, Katz SG, Tu HC, Kim $\mathrm{H}$, Cheng EH, Tjandra N, Walensky LD (2008) BAX activation is initiated at a novel interaction site. Nature 455:1076-1081.

Genc K, Genc S, Kizildag S, Sonmez U, Yilmaz O, Tugyan K, Ergur B, Sonmez A, Buldan Z (2003) Methamphetamine induces oligodendroglial cell death in vitro. Brain Res 982:125-130.

Gibson ME, Han BH, Choi J, Knudson CM, Korsmeyer SJ, Parsadanian M, Holtzman DM (2001) BAX contributes to apoptotic-like death following neonatal hypoxia-ischemia: evidence for distinct apoptosis pathways. Mol Med 7:644-655.

Gómez-Lázaro M, Gallindo MF, Melero-Fernández de Mera RM, FernándezGómez FJ, Concannon CG, Segura MF, Comella JX, Prehn JH, Jordan J (2007) Reactive oxygen species and p38 mitogen-activated protein kinase activate bax to induce mitochondrial cytochrome $c$ release and apoptosis in response to malonate. Mol Pharmacol 71:736-743.

Goping IS, Gross A, Lavoie JN, Nguyen M, Jemmerson R, Roth K, Korsmeyer SJ, Shore GC (1998) Regulated targeting of BAX to mitochondria. J Cell Biol 143:207-215.

Grynkiewicz G, Poenie M, Tsien RY (1985) A new generation of $\mathrm{Ca}^{2+}$ indicators with greatly improved fluorescence properties. J Biol Chem 260:3440-3450

Hajnóczky G, Robb-Gaspers LD, Seitz MB, Thomas AP (1995) Decoding of cytosolic calcium oscillations in the mitochondria. Cell 82:415-424.

Hengartner MO (2000) The biochemistry of apoptosis. Nature 407:770-776.

Hossain S, Liu HN, Nguyen M, Shore G, Almazan G (2009) Cadmium exposure induces mitochondria-dependent apoptosis in oligodendrocytes. Neurotoxicology 30:544-554.

Hsu YT, Wolter KG, Youle RJ (1997) Cytosol-to-membrane redistribution of Bax and Bcl-XL during apoptosis. Proc Natl Acad Sci U S A 94:3668-3672.

Itoh T, Itoh A, Pleasure D (2003) Bcl-2-related protein family gene expression during oligodendroglial differentiation. J Neurochem 85:1500-1512.

Jamin N, Junier MP, Grannec G, Cadusseau J (2001) Two temporal stages of oligodendroglial response to excitotoxic lesion in the grey matter of the adult rat brain. Exp Neurol 172:17-28.

Khorchid A, Fragoso G, Shore G, Almazan G (2002) Catecholamineinduced oligodendrocyte cell death in culture is developmentally regulated and involves free radical generation and differential activation of caspase-3. Glia 40:283-299.

Kim JY, Kim KM, Nan JX, Zhao YZ, Park PH, Lee SJ, Sohn DH (2003) Induction of apoptosis by tanshinone I via cytochrome $\mathrm{c}$ release in activated hepatic stellate cells. Pharmacol Toxicol 92:195-200.

Kuwana T, Bouchier-Hayes L, Chipuk JE, Bonzon C, Sullivan BA, Green DR, Newmeyer DD (2005) BH3 domains of BH3-only proteins differentially regulate Bax-mediated mitochondrial membrane permeabilization both directly and indirectly. Mol Cell 17:525-535.

Lenaz G, Bovina C, D’Aurelio M, Fato R, Formiggini G, Genova ML, Giuliano G, Merlo Pich M, Paolucci U, Parenti Castelli G, Ventura B (2002) Role of mitochondria in oxidative stress and aging. Ann NY Acad Sci 959:199-213.

Lev N, Barhum Y, Melamed E, Offen D (2004) Bax-ablation attenuates ex- 
perimental autoimmune encephalomyelitis in mice. Neurosci Lett 359:139-142.

Lin CH, Lu YZ, Cheng FC, Chu LF, Hsueh CM (2005) Bax-regulated mitochondria-mediated apoptosis is responsible for the in vitro ischemia induced neuronal cell death of Sprague Dawley rat. Neurosci Lett 387:22-27.

Liu HN, Giasson BI, Mushynski WE, Almazan G (2002) AMPA receptormediated toxicity in oligodendrocyte progenitors involves free radical generation and activation of JNK, calpain and caspase 3. J Neurochem 82:398-409.

Liu Y, Pu Y, Zhang X (2006) Role of the mitochondrial signalling pathway in murine coronavirus-induced oligodendrocyte apoptosis. J Virology 80:395-403.

Lovell JF, Billen LP, Bindner S, Shamas-Din A, Fradin C, Leber B, Andrews DW (2008) Membrane binding by tBid initiates an ordered series of events culminating in membrane permeabilization by Bax. Cell 135:1074-1084.

Madison DL, Pfeiffer SE (1996) Cloning of the $3^{\prime}$ end of rat bax alpha and corresponding developmental down-regulation in differentiating primary, cultured oligodendrocytes. Neurosci Lett 220:183-186.

Mansouri B, Henne WM, Oomman SK, Bliss R, Attridge J, Finckbone V, Zeitouni T, Hoffman T, Bahr BA, Strahlendorf HK, Strahlendorf JC (2007) Involvement of calpain in AMPA-induced toxicity to rat cerebellar Purkinje neurons. Eur J Pharmacol 557:106-114.

Matute C (1998) Characteristics of acute and chronic kainate excitotoxic damage to the optic nerve. Proc Natl Acad Sci U S A 95:10229-10234.

Matute C, Sánchez-Gómez MV, Martínez-Millán L, Miledi R (1997) Glutamate receptor-mediated toxicity in optic nerve oligodendrocytes. Proc Natl Acad Sci U S A 94:8830-8835.

McDonald JW, Althomsons SP, Hyrc KL, Choi DW, Goldberg MP (1998) Oligodendrocytes from forebrain are highly vulnerable to AMPA/kainate receptor-mediated excitotoxicity. Nat Med 4:291-297.

Nechushtan A, Smith CL, Hsu YT, Youle RJ (1999) Conformation of the Bax C-terminus regulates subcellular location and cell death. EMBO J 18:2330-2341.

Ness JK, Scaduto RC Jr, Wood TL (2004) IGF-I prevents glutamatemediated Bax translocation and cytochrome $\mathrm{C}$ release in $\mathrm{O} 4+$ oligodendrocyte progenitors. Glia 46:183-194.

Nixon RA (2003) The calpains in aging and aging-related diseases. Ageing Res Rev 2:407-418.

Oh SH, Lee BH, Lim SC (2004) Cadmium induces apoptotic cell death in WI 38 cells via caspase-dependent Bid cleavage and calpain-mediated mitochondrial Bax cleavage by Bcl-2-independent pathway. Biochem Pharmacol 68:1845-1855.

Osterhout DJ, Marin-Husstege M, Abano P, Casaccia-Bonnefil P (2002) Susceptibility to apoptosis in differentiating oligodendrocytes. J Neurosci Res 69:24-29.

Owens TW, Valentijn AJ, Upton JP, Keebke J, Zhang L, Lindsay J, Zouq NK, Gilmore AP (2009) Apoptosis commitment and activation of mitochondrial Bax during anoikis is regulated by p38MAPK. Cell Death Diff 16:1551-1562.

Pang Y, Zheng B, Fan LW, Rhodes PG, Cai Z (2007) IGF-1 protects oligodendrocyte progenitors against TNF $\alpha$-induced damage by activation of PI3K/Akt and interruption of the mitochondrial apoptotic pathway. Glia 55:1099-1107.

Park EJ, Zhao YZ, Kim YC, Sohn DH (2007) Bakuchiol-induced caspase-3dependent apoptosis occurs through c-Jun NH2-terminal kinasemediated mitochondrial translocation of Bax in rat liver myofibroblasts. Eur J Pharmacol 559:115-123.

Pérez-Navarro E, Gavaldà N, Gratacòs E, Alberch J (2005) Brian-derived neurotrophic factor prevents changes in Bcl-2 family members and caspase- 3 activation induced by excitotoxicity in striatum. J Neurochem 92:678-691.
Perier C, Bové J, Wu DC, Dehay B, Choi DK, Jackson-Lewis V, RathkeHartlieb S, Bouillet P, Strasser A, Schulz JB, Przedborski S, Vila M (2007) Two molecular pathways initiate mitochondria dependent dopaminergic neurodegeneration in experimental Parkinson's disease. Proc Natl Acad Sci U S A 104:8161-8166.

Polster BM, Fiskum G (2004) Mitochondrial mechanisms of neural cell apoptosis. J Neurochem 90:1281-1289.

Rami A (2003) Ischemic neuronal death in the rat hippocampus: the calpain-calpastatin-caspase hypothesis. Neurobiol Dis 13:75-88.

Reed JC (1998) Bcl-2 family proteins. Oncogene 17:3225-3236.

Sánchez-Gómez MV, Matute C (1999) AMPA and kainate receptors each mediate excitotoxicity in oligodendroglial cultures. Neurobiol Dis 6:475-485.

Sánchez-Gómez MV, Alberdi E, Ibarretxe G, Torre I, Matute C (2003) Caspase-dependent and caspase-independent oligodendrocyte death mediated by AMPA and kainate receptors. J Neurosci 23:9519-9528.

Skulachev VP (2006) Bioenergetic aspects of apoptosis, necrosis and mitoptosis. Apoptosis 11:473-485.

Steckley D, Karajgikar M, Dale LB, Fuerth B, Swan P, Drummond-Main C, Poulter MO, Ferguson SS, Strasser A, Cregan SP (2007) Puma is a dominant regulator of oxidative stress induced Bax activation and neuronal apoptosis. J Neurosci 27:12989-12999.

Stout AK, Raphael HM, Kanterewicz BI, Klann E, Reynolds IJ (1998) Glutamate-induced neuron death requires mitochondrial calcium uptake. Nat Neurosci 1:366-373.

Tafani M, Cohn JA, Karpinich NO, Rothman RJ, Russo MA, Farber JL (2002) Regulation of intracellular $\mathrm{pH}$ mediates Bax activation in HeLa cells treated with staurosporine or tumor necrosis factor-alpha. J Biol Chem 277:49569-49576.

Tehranian R, Rose ME, Vagni V, Pickrell AM, Griffith RP, Liu H, Clark RS, Dixon CE, Kochanek PM, Graham SH (2008) Disruption of Bax protein prevents neuronal cell death but produces cognitive impairment in mice following traumatic brain injury. J Neurotrauma 25:755-767.

Tikhomirov O, Carpenter G (2005) Bax activation and translocation to mitochondria mediate EGF-induce programmed cell death. J Cell Sci 118:5681-5690.

Toyota H, Yanase N, Yoshimoto T, Moriyama M, Sudo T, Mizuguchi J (2003) Calpain-induced Bax-cleavage product is a more potent inducer of apoptotic cell death than wild-type Bax. Cancer Lett 189:221-230.

Tsujimoto Y (2003) Cell death regulation by the Bcl-2 protein family in the mitochondria. J Cell Physiol 195:158-167.

Vila M, Jackson-Lewis V, Vukosavic S, Djaldetti R, Liberatore G, Offen D, Korsmeyer SJ, Przedborski S (2001) Bax ablation prevents dopaminergic neurodegeneration in the 1-methyl-4-phenyl-1,2,3,6-tetrahydropyridine mouse model of Parkinson's disease. Proc Natl Acad Sci U S A 98:2837-2842.

Ward MW, Kögel D, Prehn JH (2004) Neuronal apoptosis: BH3-only proteins the real killers? J Bioenerg Biomembr 36:295-298.

Wood DE, Newcomb EW (2000) Cleavage of Bax enhances its cell death function. Exp Cell Res 256:375-382.

Wood DE, Thomas A, Devi LA, Berman Y, Beavis RC, Reed JC, Newcomb EW (1998) Bax cleavage is mediated by calpain during drug-induced apoptosis. Oncogene 17:1069-1078.

Wu X, Deng Y (2002) Bax and BH3-domain-only proteins in p53-mediated apoptosis. Front Biosci 7:151-156.

Wu Y, Xing D, Chen WR, Wang X (2007) Bid is not required for Bax translocation during UV-induced apoptosis. Cell Signal 19:2468-2478.

Yoshioka A, Bacskai B, Pleasure D (1996) Pathophysiology of oligodendroglial excitotoxicity. J Neurosci Res 46:427-437.

Yung HW, Bal-Price AK, Brown GC, Tolkovsky AM (2004) Nitric oxideinduced cell death of cerebrocortical murine astrocytes in mediated through p53- and bax-dependent pathways. J Neurochem 89:812-821. 